\title{
Aplikasi Transaksi Jual Beli Perhiasan Emas berbasis Android
}

\author{
Candra Agustina \\ Universitas Bina Sarana Informatika \\ Sistem Informasi Akuntansi Kampus Kota Surakarta \\ Jakarta, Indonesia \\ Email:candra.caa@bsi.ac.id
}

\begin{abstract}
Gold Shop is a business of buying and selling gold, both in the form of jewelry and in the form of bars. Transactions carried outsell and buy gold jewelry, with different buying and selling prices. In a gold shop, to sell jewelry a clerk needs to write down the weight, and draw the model in a sales letter or memorandum. The problem that occurs is the ability to draw from employees who are not the same, some can draw jewelry similar to the original, some are unclear. Jewelry letters are also sometimes lost in the hands of customers so when selling must first ascertain whether the jewelry originates from this store. Therefore, it is necessary to make an information system to facilitate the process of buying and selling gold jewelry. The system is made based on Android because it can utilize the mobile phones of each employee. The system is made using the Rapid Application Development method, to get the final result of an android-based application. This method consists of 3 stages, namely the needs plan, the system design process, and implementation. This gold jewelry sale and purchase application consists of 2 users namely shop owners and employees. The function of the owner application is to see the number of items sold jewelry purchased, daily, weekly and monthly financial statements. The application has the advantage of updating the price of gold, both selling and buying in realtime. Using this application can speed up transactions, create reports, and reduce errors in recording transactions.
\end{abstract}

\section{Keywords-RAD, Android, Transaction}

Abstrak - Toko Emas adalah sebuah usaha jual beli emas, baik berupa perhiasan maupun dalam bentuk batangan. Transaksi yang dilakukan menjual dan membeli perhiasan emas, dengan harga jual dan beli yang berbeda. Disebuah toko emas, untuk menjual sebuah perhiasan petugas perlu menuliskan berat, dan menggambar modelnya dalam surat atau nota penjualan. Permasalahan yang terjadi adalah kemampuan menggambar dari pegawai yang tidak sama, ada yang bisa menggambar perhiasan mirip sesuai aslinya, ada yang kurang jelas. Surat perhiasan terkadang juga hilang di tangan pelanggan sehingga ketika menjual harus memastikan dulu apakah benar perhiasan tersebut berasal dari toko ini. Oleh karena itu, perlu dibuat sebuah sistem informasi untuk memudahkan dalam proses jual beli perhiasan emas. Sistem yang dibuat berbasis android karena bisa memanfaatkan handphone milik masing-masing karyawan. Sistem dibuat menggunakan metode Rapid Application Development, untuk mendapatkan hasil akhir sebuah aplikasi berbasis android. Metode ini terdiri dari 3 tahapan, yaituo rencana kebutuhan, proses desain sistem dan implementasi. Aplikasi jual beli perhiasan emas ini terdiri dari 2 user yaitu pemilik dan karyawan toko. Fungsi dari aplikasi pemilik adalah melihat jumlah barang yang terjual, perhiasan yang dibeli, laporan keuangan harian, mingguan dan bulanan. Selain itu aplikasi mempunyai kelebihan update harga emas baik jual maupun beli secara realtime. Dengan digunakannya aplikasi tersebut dapat mempercepat transaksi, pembuatan laporan, dan mengurangi kesalahan dalam pencatatan transaksi.

\section{Kata Kunci : RAD, Android, Transaksi}

\section{PENDAHULUAN}

Toko Emas merupakan sebuah usaha jual beli perhiasan emas dan juga emas batangan. Selama ini proses transaksi menggunakan surat penjualan yang diberikan oleh karyawan toko, dan harus disimpan selama perhiasan emas tersebut belum dijual. Sebuah toko emas mempunyai beberapa cabang di kota magelang, ketika menjual sebuah perhiasan, karyawan toko menuliskan nama, alamat, dan nomor telepon pelanggan. Selain itu juga harus memasukkan datadata perhiasan yang dijual, termasuk didalamnya harus menggambar model dari perhiasan tersebut. Untuk membuat sebuah surat memerlukan waktu relatif lama dan kemungkinan besar terjadi kesalahan. Hasil gambar karyawan juga menjadi masalah tersendiri karena bergantung kemampuan masing-masing karyawan.

Oleh karena itu perlu dibuat sebuah sistem yang berfungsi untuk mempermudah seluruh transaksi yang dilakukan. Dalam kesehariannya, toko emas melakukan transaksi penjualan dan pembelian perhiasan dari pelanggan. Akan tetapi toko hanya membeli perhiasan yang berasal dari toko tersebut atau toko cabang. Sedangkan perhiasan dari toko lain tidak bisa dibeli oleh toko tersebut. Selama ini pengenal utama asal dari sebuah perhiasan adalah surat penjualan. Ketika surat tersebut hilang, akan lebih sulit mengenali bahwa perhiasan tersebut berasal dari toko yang sama. Oleh karena itu surat atau nota penjualan tersebut tidak boleh hilang. 
Dalam transaksi jual beli emas terdapat perbedaan dengan transkasi jual beli barang pada umumnya. Perbedaan tersebut terletak pada :

1. Harga jual emas yang dapat mengalami perubahan setiap saat, sehingga sistem informasi harus selalu update.

2. Perhiasan emas yang dijual harus berasal dari toko emas tersebut yang sebelumnya dibeli oleh pelanggan. Jadi toko emas tidak menerima produk perhiasan emas dari toko lain. Jadi pelanggan yang menjual adalah pelanggan yang sebelumnya telah membeli perhiasan tersebut. Dalam transaksi konvensional dibuktikan dengan surat jual beli.

3. Transaksi pembelian mengikuti harga emas yang berlaku saat itu dengan potongan tertentu.

Untuk mengatasi permasalahan diatas akan dibuat sebuah sistem informasi menggunakan metode RAD. Pada penelitian sebelumnya metode ini berhasil digunakan untuk merancang sebuah program inventory berbasis website dan menjadikan pekerjaan lebih efisien[1]. Metode RAD ini mempunyai masa pengembangan perangkat lunak yang lebih pendek yaitu 30 sampai 90 hari[2]. Dengan waktu pembuatan yang lebih singkat ini berarti juga sistem akan lebih cepat digunakan.

Sedangkan android digunakan karena masyarakat Indonesia sudah terbiasa menggunakan perangkat tersebut. Dari sisi pengembang software android lebih fleksibel digunakan karena bersifat open source. Toko Emas tersebut juga membutuhkan perangkat yang mobile dan mudah digunakan karyawan. Mempunyai perangkat masing-masing yang tidak mungkin didapatkan dalam sebuah Personal Computer atau PC.

Pada penelitian sebelumnya Ramadana dkk mengembangakn sistem informasi jual beli perhiasan perak berbasis desktop. Fitur utamanya yaitu mengelola transaksi penjualan dan pembelian, pengelolaan stok barang, laporan keuangan, pembayaran sales. Hasil akhirnya program dapat berjalan dengan baik dengan hasil pengujian sebesar $100 \%$. [3]. Yulia dalam penelitian berjudul perancangan program penjualan perhiasan emas pada toko mas dan permata renny medan membuat sistem informasi berbasis desktop. Menggunakan bahasa pemrograman Visual Basic 6.0[4]. Kelemahan dari dua penelitian tersebut adalah masih menggunakan perangkat komputer sehingga dirasa kurang mobile.

\section{LANDASAN TEORI}

\section{A. Rapid Application Development dan Rapid Prototyping}

Metode Rapid Application Develompent merupakan bagian dari model prototyping yang paling banyak digunakan. Menekankan pada kecepatan waktu pada setiap tahapan, oleh karena itu maka proses juga harus didukung oleh perangkat yang cepat[5].

Dalam metode Rapid Appilcation Development terdiri dari tiga tahapan, yaitu,

\section{Analisis Kebutuhan}

Dilakukan oleh user dan manajer proyek untuk menentukan tujuan dari pembuatan sistem, kebutuhan informasi apa saja yang dibutuhkan oleh semua user dan pemangku kepentingan yang terlibat.

2. Desain
Desain meliputi desain database, user interface, maupun jaringan. Dalam tahap ini user dapat memberikan masukan-masukan apabila ada yang dinilai belum sesuai.

3. Implementasi

Implementasi dilaksanakan jika telah disepakati oleh user dan pengembang. Sebelum diimplementasikan sistem terlebih dulu mengalami tahap pengujian[2].

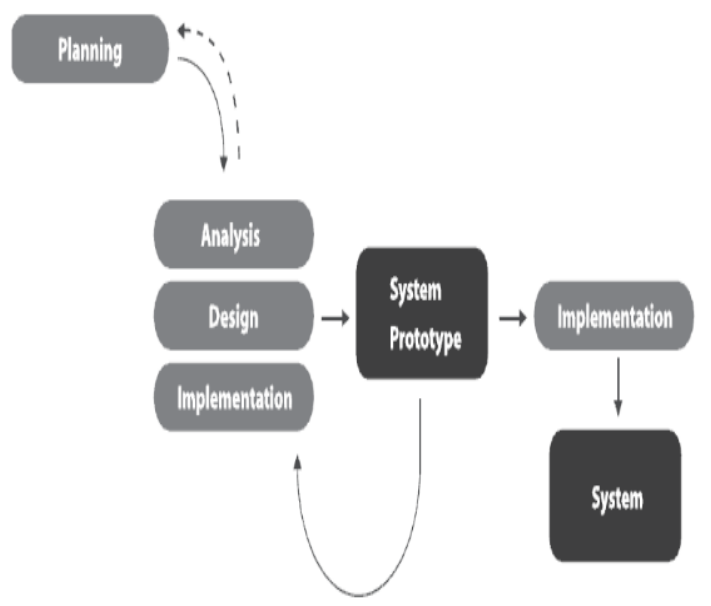

Gambar 1. RAD dan Rapid Prototyping [5]

\section{B. Unified Modelling Language}

Unified Modelling Language merupakan gambar untuk memvisualisasi,spesifikasi membangun dan proses dokumentasi dari pengembangan software berbasis Objeck Oriented.

Dalam Unified Modelling Language terdapat diagramdiagram sebagai berikut:

1. Use Case

Use case adalah penggambaran dari sisi external view, dari sebuah sistem. Menunjukkan peran antar aktor dalam sebuah sistem.

2. Class Diagram

Yang dimaksud class diagram adalah sebuah set objek yang memiliki atribut dan perilaku yang sama. Kelas memiliki 3 bagian pokok yaitu nama, atribut dan operasi.

3. Activity Diagram

Diagram aktivitas menunjukkan kegiatan sistem dalam bentuk kumpulan aksi. Harus dapat menggambarkan bagaimana sistem dimulai, aksi apa saja yang terjadi, kemudian sampai selesai proses tersebut.

4. Squence Diagram

Suence Diagram menggambarkan urutan tahapan dalam sistem yang dibangun. Dan harus sesuai dengan use cae yang telah dibuat sebelumnya.[6]

\section{Android Software Development}

Pengembangan software android adalah proses membuat aplikasi baru sebuah proses untuk membuat sebuah aplikasi baru berbasis android. Aplikasi ini dibuat menggunakan bahasa pemrograma Java dan Android SDK (Software Development Kit). Android SDK mencakup seperangkat alat pengembang yang bersifat 
komperehensif. Didalamnya terdapat debugger, libraries, emulator, dokumentasi, sampel, tutorial. Android SDK dapat berjalan pada sistem operasi Lnux, Mac Os, dan windows.[7]

D. SQLite

Database yang biasa digunakan untuk apliaksi android adalah SQLite yang merupkana database mutakhir, mudah dioperasikan dan di dukung oleh banyak platform.

Keunggulan SQLlite dibandingkan dengan SQL dan MySQL:

1. SQLite berbasis file, sedangkan SQL dan MySQL berbasis server.

2. Dapat disematkan dalam proses sistem manajemen basisdata relational

3. Ringan dan sistem amanjemen basis data nya sesuai untuk pemrograman berbasis mobile.

4. SQLite tidak memerlukan server khusus[8].

\section{HASIL DAN PEMBAHASAN}

A. Indentifikasi Kebutuhan

Dalam identifikasi kebutuhan terdapat beberapa sub atau bagian sebagai berikut :

1. Kebutuhan Pengguna

User yang akan menggunakan sistem ini adalah manajer, karyawan toko, dan pelanggan atau customer.

Manajer sebagai top level management dapat melihat semua transaksi yang terjadi, dapat dilihat perhari, perminggu sampai per bulan. Manajer juga bertugas untuk memverifikasi transaksi yang akna dilakukan oleh karyawan. Baik transaksi penjualan maupun pembelian.

Karyawan toko menggunakan aplikasi untuk melakukan penjualan dan pembelian. Ketika melakukan penjualan, karyawan wajib menginputkan id pelanggan, jenis perhiasan, berat, harga jual, dan foto perhiasan.

Pelanggan menggunakan aplikasi untuk validasi pembelian, perhiasan yang dibeli masuk kedalam aplikasi, beserta perkiraan nilai jual saat ini. Ketika ingin melakukan penjualan, pelanggan tinggal memilih perhiasan yang akan dijual kemudian klik jual dan menunggu validasi dari karyawan. Perhiasan yang berhasil dijual akan terhapus dari base pelanggan.

2. Kebutuhan Perangkat keras

Perangkat keras yang dibutuhkan adalah 1 buah PC, dan sejumlah mobile phone berbasis android sebanyak karyawan yang melayani transaksi penjualan dan pembelian.

3. Kebutuhan Perangkat Lunak

Perangkat lunak yang dibutuhkan adalah android dan web server.

B. Desain Sistem

Use Case

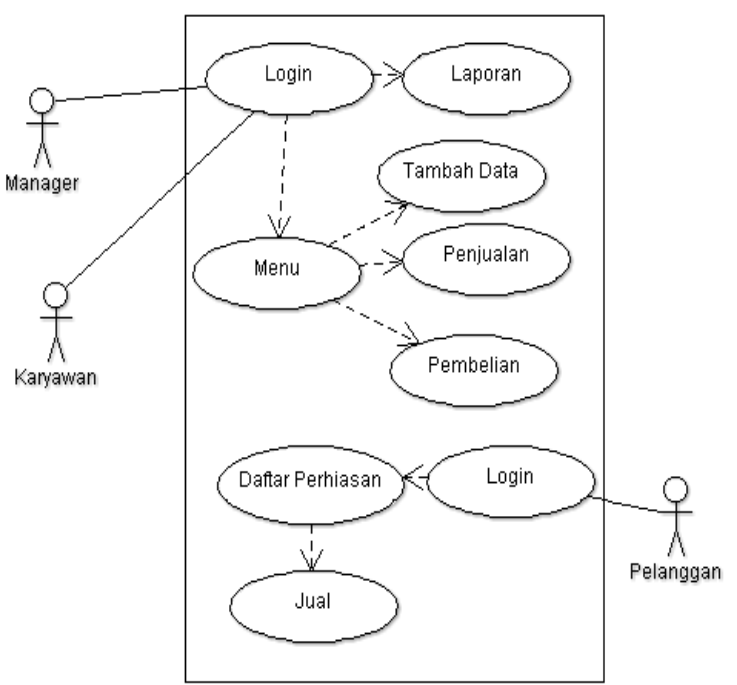

Gambar 2. Use Case Aplikasi

\section{Class Diagram}

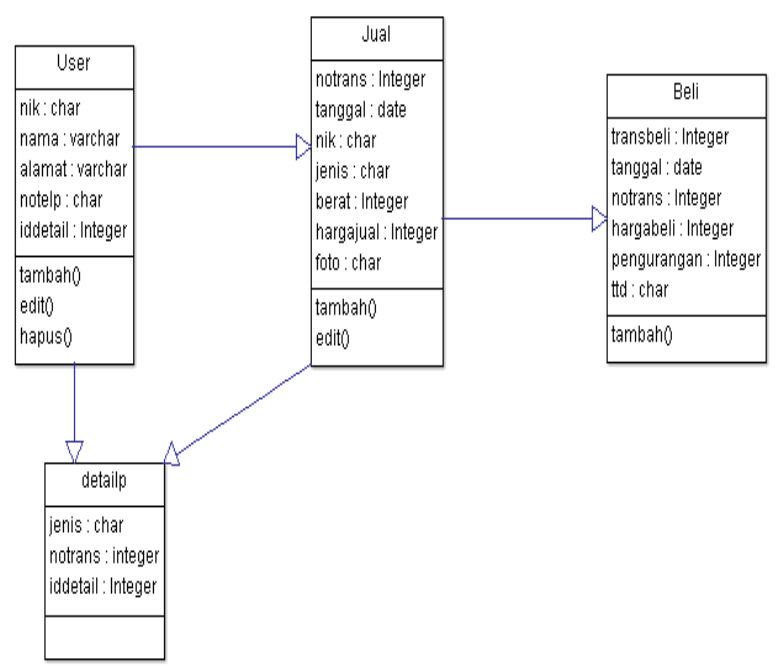

Gambar 3. Class Diagram

Desain User Interface

Sistem dibuat, menggunakan 2 aplikasi, satu aplikasi untuk karyawan. Dan 1 aplikasi untuk pelanggan. Manager dimasukkan kedalam kategori karyawan. Pengolahan data pelanggan dilakukan dengan komputer.

- Manager

Form Login

Sebelum dapat melihat laporan penjualan dan pembelian, seorang manager harus melakukan login dulu pada aplikasi. Jika Login berhasil maka manager akan diarahkan ke form menu. 


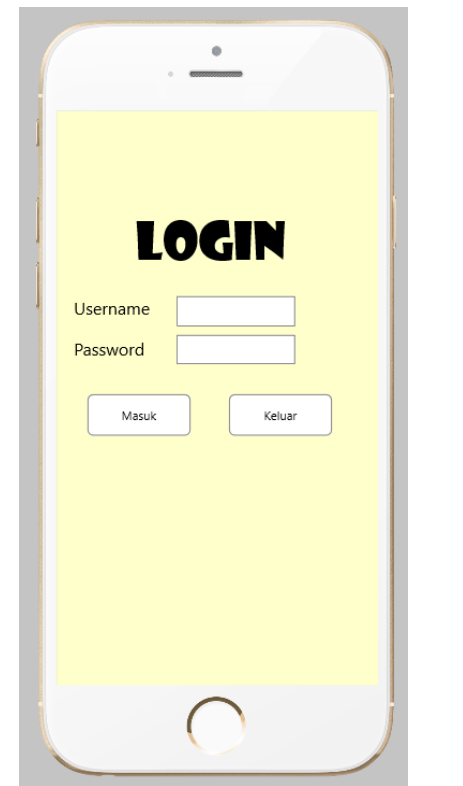

Gambar 4. Form Login Manager

\section{Menu}

Manager dapat masuk kedalam menu laporan penjualan dan pembelian. Menu yang dipilih bisa harian, mingguan dan bulanan. File dapat di lihat online maupun langung didownload.

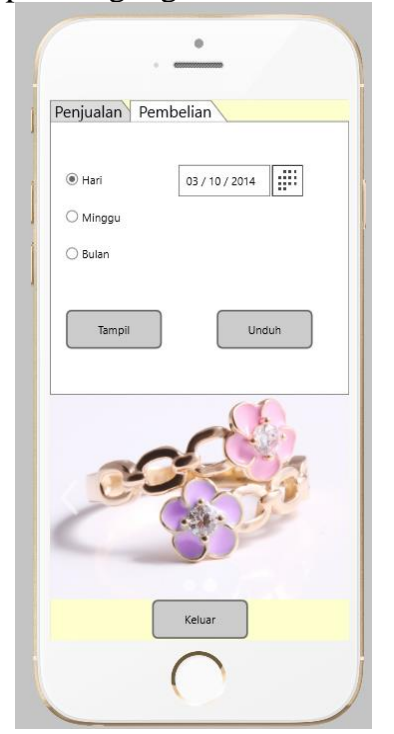

\section{Gambar 5 Tampilan Pilihan Laporan}

Karyawan

Menu Utama

Pada menu utama karyawan dapat memilih transaksi yang akan dilakukan. Menu yang bisa dipilih adalah tambah data pelanggan, Penjualan, Pembelian.

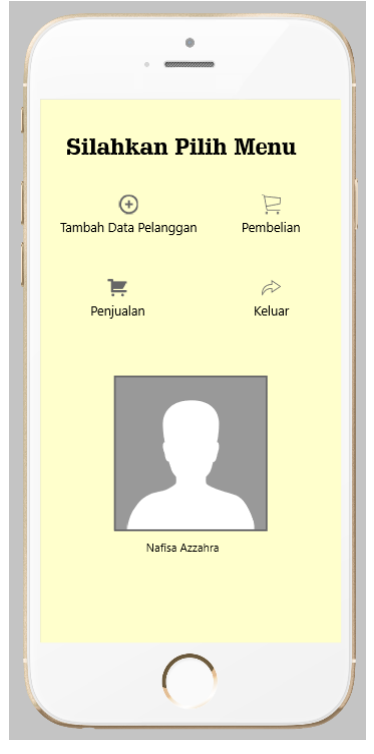

Menu Jual

Form penjualan diisi NIK Pelanggan, akan memunculkan nama, alamat, dan nomor telepon. Memlilih jenis perhiasan, input berat, kemudian ambil foto. Sentul tombol proses untuk melakukan transaksi, sentuh batal untuk membatalkan transaksi.

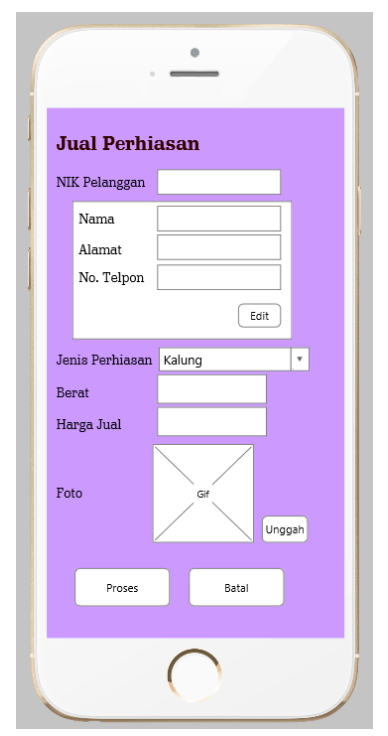

\section{Gambar 6. Form Transaksi Penjualan}

Menu Beli

Sebelum memproses transaksi pembelian, karyawan akan mendapatkan notifikasi sebagai berikut. 


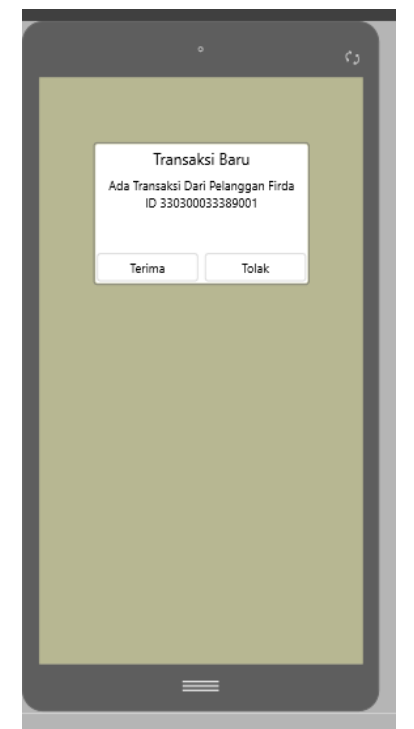

\section{Gambar 7. Pemberitahuan Permintaan} Transaksi Pembelian

Menu Input Transaksi Beli

Untuk transaksi pembelian, karyawan menginputkan NIK Pelanggan, maka akan tampil, nama, alamat, dan nomor telepon. Jenis perhiasan, berat awal muncul otomatis, sedangkan pengurangan dan berat akhir diinputkan. Kolom tanda tangan merupakan persetujuan pelanggan untuk melakukan transaksi.

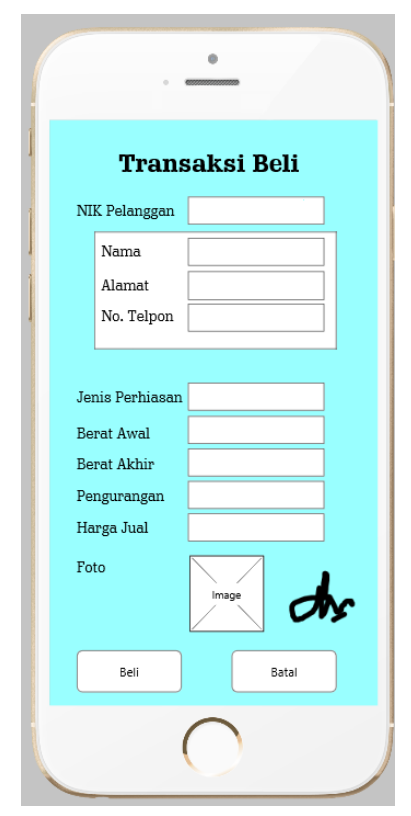

\section{Gambar 8. Input Transaksi Beli}

Pelanggan

Menu Daftar Perhiasan

Form ini akan menampilkan seluruh perhiasan yang telah dibeli oleh pelanggan. Pelanggan bisa melihat klik detail untuk melihat data perhiasan tersebut.

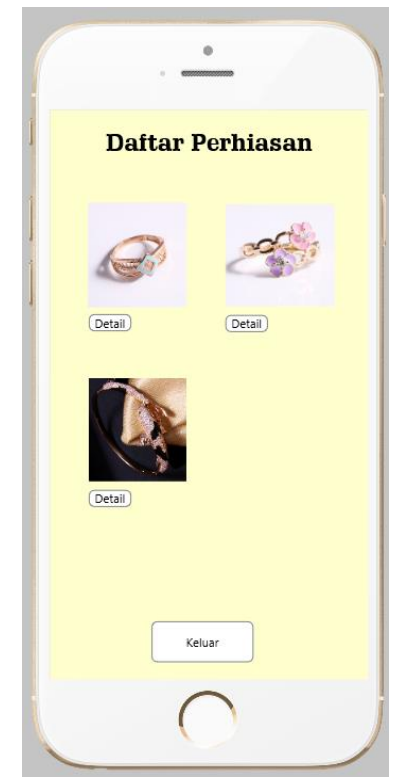

\section{Gambar 9. Menu Daftar Perhiasan}

Detail Perhiasan

Detail barang menampilkan Foto, dan data-data perhiasan. Jika Pelanggan ingin menjual maka di sentuh tombol jual.

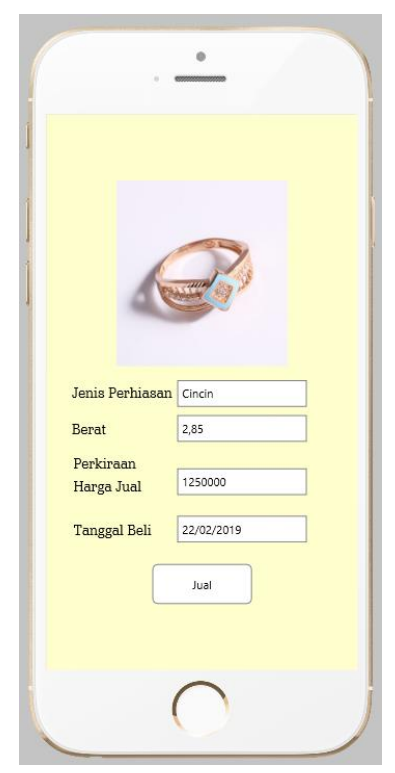

Gambar 10. Detail Barang

\section{Konfirmasi}

Ketika klik Jual maka akan muncul konfirmasi apakah yakin akan menjual perhiasan yang dimaksud. Jika memilih jual maka harus memasukan id dari karyawan yang melayani. Kemudian sentuh tombol OK untuk melanjutkan proses. 


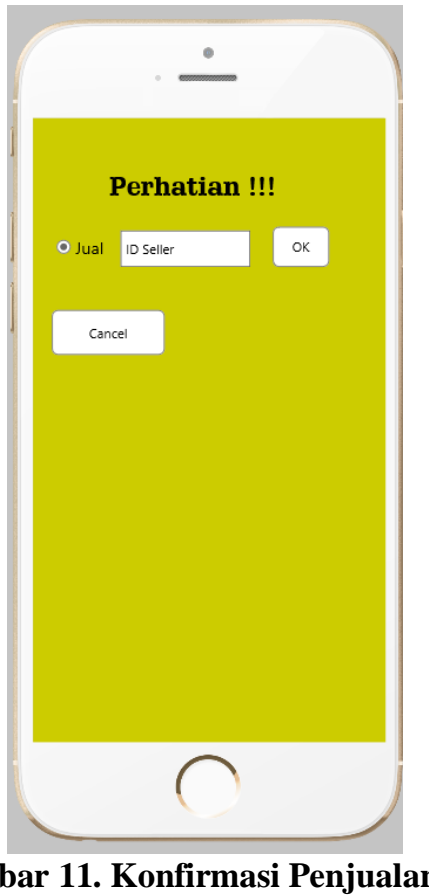

C. Pegujian

Pengujian dilakukan dengan menggunakan blackbox testing. Yaitu dengan menguji fungsi dari fitur-fitur yang ada pada user interface.

D. Implementasi

Implementasi dilakukan dengan metode parallel, artinya sistem yang sebelumnya masih digunakan. Hal ini dilakukan untuk mengantisipasi pelanggan yang belum paham sistem informasi dan teknologi.

\section{KESIMPULAN DAN SARAN}

Kesimpulan

1. Aplikasi yang dibuat dapat mempercepat transaksi penjualan dan pembelian.

2. Laporan juga dapat disajikan secara real time dan mengurangi kesalahan yang terjadi sebelumnya seperti terjadi selisih antara laporan dengan barang yang dijual atau dibeli.

3. Tenaga yang dikeluarkan juga lebih efisien, karena karyawan tidak perlu menggambar bentuk perhiasan lagi melainkan digantikan dengan foto.

Saran

1. Menggunakan pengolahan citra digital untuk mengenali perhiasan emas.

2. Melakukan sosisalisasi yang terus menerus kepada seluruh user, agar tujuan penggunaan sistem dapat tercapai.

3. Memanfaatkan teknologi RFID untuk membaca Kartu Tanda Penduduk elektronik.

4. Melakukan pengamanan sistem dan backup data secara rutin dan terus menerus.

\section{PENGHARGAAN}

Terima kasih saya ucapkan kepada toko emas langganan saya yan menjadi inspirasi penulisan karya ilmiah ini. Juga
Institusi saya Universitas Bina Sarana Informatika yang selalu memberikan arahan untuk pengembangan diri bagi para dosennya. Dan tidak lupa kepada teman-teman di kampus Surakarta dan Yogyakarta yang selalu siap membantu.

\section{REFERENSI}

[1] J. R. Sagala, "Model Rapid Application Development ( Rad ) Dalam Pengembangan Sistem Informasi Penjadwalan," J. Mantik Penusa, vol. 2, no. 1, pp. 87-90, 2018.

[2] T. Wahyuningrum and D. Januarita, "Perancangan Web e-Commerce dengan Metode Rapid Application Development ( RAD ) untuk Produk Unggulan Desa," vol. 2014, no. November, pp. 8188, 2014.

[3] N. Ramadana, D. S. Rusdianto, and B. Priyambadha, "Sistem Pengelolaan Transaksi Toko Perhiasan Perak Berbasis Desktop ( Studi Kasus: Toko Perak Beben Banjarmasin )," J. Pengemb. Teknol. Inf. dan Ilmu Komput. Univ. Brawijaya, vol. 2, no. 11, pp. 5081-5088, 2018.

[4] eka rini Yulia, "Perancangan Program Penjualan Emas," J. Evolusi Vol. 5 No 22017Evolusi.Bsi.Ac.Id, vol. 5, no. 2, pp. 27-34, 2017.

[5] A. P. Salim, P. Chithra, and S. Sreeja, "Survey on Different Process Models Used In Software Development," vol. 5, no. 3, pp. 2855-2860, 2014.

[6] Suendri, "Implementasi Diagram UML (Unified Modelling Language) Pada Perancangan Sistem Informasi Remunerasi Dosen Dengan Database Oracle (Studi Kasus: UIN Sumatera Utara Medan)," J. Ilmu Komput. dan Inform., vol. 3, no. 1, pp. 1-9, 2018.

[7] S. Mukherjee, P. J. Prakash, and D. Kumar, "Android Application Development \& Its Security," Int. J. Comput. Sci. Mob. Comput., vol. 4, no. 3, pp. 714-719, 2015.

[8] S. T. Bhosale, M. T. Patil, and M. P. Patil, "SQLite: Light Database System," Int. J. Comput. Sci. Mob. Comput., vol. 44, no. 4, pp. 882-885, 2015. 